\title{
MODIFICATION OF RESERVOIR CHEMICAL AND PHYSICAL FACTORS IN STEAMFLOODS TO INCREASE HEAVY OIL RECOVERY
}

Contract Number: DE-FG22-93BC14899

University of Southern California

Contract Date: February 22, 1993

Anticipated Completion Date: February 21, 1996

Government Award (for current year): $\$ 150,000$

Principal Investigator: Yanis C. Yortsos

Contracting Officer's Representative (COR): Thomas B. Reid

Reporting Period: January 1 - March 31, 1996

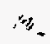

\author{
DISCLAIMER
}

This report was prepared as an account of work sponsored by an agency of the United States Government. Neither the United States Government nor any agency thereof, nor any of their employees, makes any warranty, express or implied, or assumes any legal liability or responsibility for the accuracy, completeness, or usefulness of any information, apparatus, product, or process disclosed, or represents that its use would not infringe privately owned rights. Reference herein to any specific commercial product, process, or service by trade name, trademark, manufacturer, or otherwise does not necessarily constitute or imply its endorsement, recommendation, or favoring by the United States Government or any agency thereof. The views and opinions of authors expressed herein do not necessarily state or reflect those of the United States Government or any agency thereof.

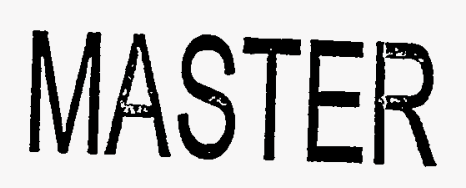




\section{DISCLAIMER}

Portions of this document may be illegible in electronic image products. Images are produced from the best available original document. 


\section{$D O E / B C / 14899-38$}

\section{MODIFICATION OF RESERVOIR CHEMICAL AND PHYSICAL FACTORS IN STEAMFLOODS TO INCREASE HEAVY OIL RECOVERY}

\section{OBJECTIVES}

Thermal methods, and particularly steam injection, are currently recognized as the most promising for the efficient recovery of heavy oil. Despite significant progress, however, important technical issues remain open. Specifically, still inadequate is our knowledge of the complex interaction between porous media and the various fluids of thermal recovery (steam, water, heavy oil, gases, and chemicals). While, the interplay of heat transfer and fluid flow with pore- and macro-scale heterogeneity is largely unexplored.

The objectives of this contract are to continue previous work and to carry out new fundamental studies in the following areas of interest to thermal recovery: displacement and flow properties of fluids involving phase change (condensation-evaporation) in porous media; flow properties of mobility control fluids (such as foam); and the effect of reservoir heterogeneity on thermal recovery. The specific projects are motivated by and address the need to improve heavy oil recovery from typical reservoirs as well as less conventional fractured reservoirs producing from vertical or horizontal wells.

\section{VAPOR-LIQUID FLOW}

During this quarter, we focused on the development of relative permeabilities during steam displacement. Two particular directions were pursued: One involves the derivation of relative permeabilties based on a recently completed work on the pore-level mechanics of steam displacement (1). Progress has been made to relate the relative permeabilities to effects such as heat transfer and condensation, which are specific to steam injection problems. The second direction involves the development of three-phase relative permeabilities using invasion percolation concepts. We have developed models that predict the specific dependence of the permeabilities of three immiscible phases (e.g. oil, water and gas) on saturations and the saturation history. Both works are still in progress. In addition, work 
continues in the analysis of the stability of phase change fronts in porous media using a macroscopic approach.

In a related study, we are investigating the effect of gravity override during injection of a gas phase (such as steam) in porous media. Published work todate cannot predict the thickness of the gravity tongue, as a function of the various process parameters. We are conducting an investigation for a homogeneous porous medium assuming a sharp interface between injected and displaced fluids. An exact solution for the shape of the interface has been obtained. We are now investigating the effect of the gravity number on the thickness and shape of the gravity tongue. A somewhat parallel effort is underway to understand and model the upwards (unstable) displacement of an overlying liquid by an updip injected vapor. Finally, we are using the results of (1) to analyze the behavior of steam displacement in a matrix-fracture system.

\section{HETEROGENEITY}

Work continues on the optimization of recovery processes in heterogeneous reservoirs by using optimal control methods. The theory addresses the injection strategy that maximizes the recovery efficiency of a multiple-well system at various defined targets (e.g. at water breakthrough, or at a fixed water cut). During the past quarter we have assembled the experimental apparatus to test the theory developed. The experimental system consists of a Hele-Shaw cell with two controlled injection wells and one production well. Preliminary results have shown that the system can be reliably used to test the optimal control theory. Current work involves conducting experiments in these geometries using as parameters the mobility ratio, and the form of heterogeneity, and improving the numerical scheme for determination of the optimal control variables.

Work continued on developing viscous fingering models, based on the concept of Transverse Flow Equilibrium (TFE), and using the theory of small fluctuations. Two technical papers were written on these subjects $(2,3)$. The first paper (2) classifies various displacement regimes in terms of the geometric aspect ratio and proposes an improved viscous fingering model for displacements of unfavorable mobility ratio. The second paper (3) deals with a specific boundary effect that appears during simulation of viscous fingering problems in 
geometries of large aspect ratio. A Ph.D. Thesis on this subject was completed (4).

On the subject of heterogeneity, work continued on the effects of correlations (for example, with the use of fractional Brownian motion statistics). We are currently investigating the development of saturation profiles during invasion percolation with gradients (e.g. due to viscous or gravity forces) in long-range correlated systems. Work was completed on the problem of inverting capillary pressure data to infer the true pore-size distribution, using a pore-network approach. A technical paper on this subject is in preparation. In preparation also is a technical paper on the identification of the permeability semi-variogram from multiple well pressure transients. Finally, we made considerable advances in the development of a theory for the effect of the flow rate on relative permeabilities and displacements in heterogeneous media (5).

\section{CHEMICAL ADDITIVES}

In the area of chemical additives work continued on the behavior of non-Newtonian fluid flow and on foam displacements in porous media. Work in this area proceeds in two parallel directions: One involves the development of a generic theory for finding the minimum threshold path in a disordered system. A technical paper was prepared on this subject (6). The other effort involves the application of this theory to pore networks to determine the conditions for foam formation and mobilization. A technical paper summarizing the results obtained is in preparation (7). 


\section{REFERENCES}

1. Satik, C., and Yortsos, Y.C., Pore Network Studies of Steam Injection in Porous Media, paper SPE 30751 presented at the 1995 SPE Fall Meeting, Dallas, TX (Oct. 22-25, 1995).

2. Yang, Z., and Yortsos, Y.C., Asymptotic Regimes in Miscible Displacements in Random Porous Media, paper SPE/DOE 35456 presented at the SPE/DOE Symposium on Improved Oil Recovery, Tulsa, OK (April 21, 1996).

3. Yang, Z., and Yortsos, Y.C., Effect of No-Flow Boundaries on Viscous Fingering in Porous Media of Large Aspect Ratio, SPEJ, submitted (1996).

4. Yang, Z., Ph.D Thesis, University of Southern California (1995).

5. Xu, B., Yortsos, Y.C., and Salin, D., Invasion Percolation with Viscous Forces, revised version, submitted (1996).

6. Kharabaf, H., and Yortsos, Y.C., Invasion Percolation with Memory, paper presented at the AICHE Fall Meeting (Nov. 1995).

7. Kharabaf, H., and Yortsos, Y.C., A Pore-Network Model for Foam Formation and Propagation in Porous Media, to be presented at the SPE Fall Meeting (Oct. 1996). 


\section{FACULTY}

Y. C. Yortsos

STUDENTS

Youngmin Choi

Changan Du

Naveen Halbhavi

Hooshang Kharabaf

Bagus Sudaryanto 